\title{
Antimicrobial Assessment of Fresh Ripe and Dry Ripe Musa sapientum $L$. Peels against Selected Isolates Associated with Urinary Tract Infection in Port Harcourt, Nigeria
}

\author{
Authors

\section{Konne, Felix Eedee, Nwokah, Easter Godwin, Wachukwu, Confidence Kinikanwo} \\ Department of Medical Laboratory Science, Rivers State University, Port Harcourt, \\ Nkpolu - Oroworukwo P.M.B. 5080, Rivers State, Nigeria \\ *Corresponding Author \\ Konne, Felix Eedee \\ Tel.: +2348035484367, Email:felixkonne.fk@gmail.com,felixkonne@yahoo.co.uk
}

\begin{abstract}
Banana peels is the outer coverage of the banana fruits commonly used to feed animals, fish and many others or thrown away as waste. Almost every part of a banana plant has medicinal values. Urinary Tract Infection is an infection that affects any parts of your urinary system (upper or lower). Usually its treatment and diagnosis are usually with antibiotics urine sample. Increase in bacterial resistant to conventional antibiotics has prompted the development of bacterial disease treatment strategies that are alternatives to conventional antibiotics.

Aim: This study is to assess the antimicrobial properties of banana peels against selected isolates from Urinary Tract Infection sample.

Methods: A Mid- stream urine samples collected from patients visiting BMSH with suspected cases of UTIs, were cultured. The isolates from culture was further analysis with agarose gel electrophoresis for the presence of 16SrRNA and Phylogenetic analysis shows Staphylococcus sciuri strain, a coagulase-negative species, Escherichia coli, Enterococcus faecalis, Klebsiella pneumoniae and Proteus mirabilis. Fresh ripe and dry ripe were used to determine the antimicrobial activities. A measure of 150grams of both fresh ripe and dry ripe was extracted with $100 \mathrm{ml}$ of both $70 \%$ ethanol and water solvent (sterile) respectively for about 2 days. The solvent extracts were concentrated separately under reduced pressure, $10 \mathrm{~g}$ of each concentrated solvent extracts were dissolved in $5 \mathrm{ml}$ of sterile distilled water and used for antimicrobial assay using agar well diffusion method.

Results: The phytochemical analysis of fresh ripe and dry ripe shows that alkaloid, flavonoid, cardiac glycosids, phenols and tannins were present. The zone of inhibition recorded from the extracts on selected organism was concentration dependent $(100 \%, 80 \%, 60 \%, 40 \%$ and 20\%). The higher the concentration the wider effect on each of the test isolates. Musa sapientum L peels showed some effect on Escherichia coli, Enterococcus faecalis, Staphylococcus sciuri, Klebsiella pneumoniae and Proteus mirabilis at 100\% and few at $80 \%$ concentrations for both solvents. Dry ripe has advantage over fresh ripe banana peels and the type of solvent (ethanol) also play a synergetic effect. The peels of Musa sapientum exhibited some inhibitory activity on these selected UTIs isolates, could be attributed to the presence of certain secondary metabolites.

Conclusion: Finally, when compared the peels extracts against the standard antibiotics drugs as my control, the water solvent extract were less effective compared to the ethanoic extracts, which were also smaller in size of their zone of inhibition.
\end{abstract}

Keywords: Fresh ripe; dry ripe banana peels; urinary tract isolates. 


\section{Introduction}

Banana peels as the name implies is the outer coverage of the banana fruits. It is commonly used in animal feeds ${ }^{[9]}$. Banana is one of the most popular food all over the whole world and the name is derived from the Arabic word "banan" meaning "finger". It has a shape "like an arch" which also contributed to the appealing nature or appearance of the fruit especially to human beings and monkeys ${ }^{[9]}$. It is a tropical fruit, which belongs to the family, Musaceae and is grown in many countries of the world ${ }^{[20]}$. Almost every part of a banana (flower, pulp, stem \& leaves) plant has medicinal values ${ }^{[10]}$. A study by ${ }^{[20]}$ has shown that banana contain some bioactive compounds which shows that it contain some pharmacological effect like antioxidant, antidiabetic, antiinflammatory and antibiotic properties.

Due to some increase in failure of some chemotherapy and the resistance of pathogen to antibiotics, this has led to several screenings of medicinal plants for potential antimicrobial functions. These medicinal plants have longer evolution of resistance against microbial agents, which has led to alternative directions in drug and chemotherapy development ${ }^{[2]}$. The increasing failure of chemotherapy and the resistance of microbial pathogens to antibiotics have led to several screenings of medicinal plants for possible antimicrobial functions ${ }^{[2]}$. These therapeutic plants have longer evolution of resistance against microbial agents, which has led to several tips in drilling and chemotherapy improvement. The availability of medicinal plants everywhere could also be the reason for the choice ${ }^{[2]}$.

Urinary Tract Infection (UTI) is an infection that can affect every parts of the urinary system for example the kidneys, bladder, ureters, and urethra. However, most urinary tract infections comprise the lower urinary tract like the bladder and the urethra $^{[8]}$. Females are at greater risk of emerging UTI than men ${ }^{[7]}$. Infection restricted to the bladder of the UTI can be so painful, annoying or bothersome. Nevertheless, severe penalties can occur if a UTI spreads to the kidneys. Usually treatment is done with antibiotics. This study is aim at the antimicrobial assessment of fresh ripe and dry ripe Musa sapientum $L$. peels against selected isolates from urinary tract infection samples.

\section{Material and Methods Collection of Ripe Banana Peels}

The ripe banana peels that were used in these investigations were obtained in same bunch from Bori General Market in Khana Local Government Area of Rivers State. This region is characterised by lengthy rainy seasons and short dry seasons with temperatures of $25-28^{\circ} \mathrm{C}$. It is situated in the southern part of Rivers State in Nigeria. The primary occupations of the people living in the area are fishing and farming ${ }^{[12]}$. The bunch of banana was identified in the Department of Plant and Environmental Science, Faculty of Science, Rivers State University, Port Harcourt. The ripe banana was washed thoroughly with water, air dried and peeled. One was prepared to shade-dried for few weeks in the Department of Medical Laboratory Science and the second was chopped fresh $^{[1]}$. Thereafter, it was also being dried in the hot air oven at a temperature of $37^{0} \mathrm{C}$ for about five days to ensure total elimination of Water (Water Availability). The dried banana peels were ground with a sterilized surface grinder, into powdery form and stored in some clean tightcapped bottles (Reagent bottle) at about $4^{0} \mathrm{C}$, with label and date ${ }^{[1]}$.

\section{Preparation of Banana Peels Extract}

One hundred and fifty grams of fresh ripe and dry ripe banana peels were coarsely chopped and blended into different solvents (Water and $70 \%$ Ethanol v/v) of $100 \mathrm{mls}$ each for extraction. This was allowed to stand for about 2-3 days at room temperature with agitation at intervals to allow for proper reaction of yellow-transparent colour, which will indicate complete reaction ${ }^{[26]}$. Thereafter, the powder (Dry ripe peels) mixture in both water and ethanol solvents were filtered using a muslin cloth. The fresh peels were blended 
and dissolved in both solvents (water and ethanol) and was filtered accordingly both the fresh ripe and dry ripe respectively ${ }^{[5]}$.

It was evaporator with water bath (Electronic thermostat water tank, Model HH.W21.Cr4211) was used for both extracts (water and ethanol) to reduce or eliminate the solvents, to obtain the (semisolid or paste) crude extract from both water and ethanol solvents respectively. The crude extract obtained was stored in a refrigerator until required for use ${ }^{[5]}$.

\section{Preparation of Stock Solution from the Extract of Banana Peels}

After complete solvents evaporation, each semisolid or paste obtained were freeze-dried (lyophilized), 10 grams of each crude extract (paste) was reconstituted in sterile distilled water of $5 \mathrm{mls}$ to obtain a stock solution of $\mathrm{mg} / \mathrm{ml}$ (mini gram per millilitre) according to the National Committee for Clinical Laboratory Standards ${ }^{[15]}$.

\section{Tests for Phytochemicals}

Phytochemical screening was performed to identify phytochemicals in the crude of the banana peels (fresh ripe) and the powder (dry) from dry ripe banana peels. Test for Alkaloids (Dragendorff test), Flavonoids detection (Shinoda's test), Tannis detection (Lead acetate test), Saponins detection (Frothing test), Cardiac glycosids detection, Steroids detection (LiebermannBurchard test), Phenols, Terpenoid, Lignans and Volatile oil were carried out using standard $\operatorname{method}^{[5]}$.

\section{Preparation of Media}

Preparation of CHROMagar ${ }^{\text {TM }}$ Orientation, Nutrient Agar and Peptone water for culture and sensitivity testing, appropriate quantities were weighed based on the required numbers of plates and manufacturers' instruction was strictly adhered to. After sterilization with autoclave
(Eschmed Medical England, Model YX-280A) at $121^{\circ} \mathrm{C}$ (15 lbs of pressure) for 15 minutes. It was then allowed to cool at temperature of about 45 to $50^{\circ} \mathrm{C}$, poured into Petri-dishes and was allowed to solidify for well diffusion ${ }^{[3],[14]}$.

\section{Source of Isolate and Culture}

Urine samples were collected from patients visiting Braithe Waite Memory Specialist Hospital with suspected cases of UTIs was involved in this study. A Mid-Stream Urine (MSU) samples were collected into sterile universal containers from the subjects who visited BMSH for Urinary Tract Infections and was cultured on CHROMagar ${ }^{\text {TM }}$ Orientation mainly for detection and differentiation of urinary tract pathogens ${ }^{[14]}$.

\section{Conventional Identification of Isolates Gram Staining Procedure}

Thereafter, with the aid of a sterile wire loop, a loopful colony of the isolated microorganisms were picked and emulsified on a clean grease free glass slide to air dried. The smear was adequately stained with freshly prepared gram staining reagents. Finally, the back of the stained slides was wiped with a cotton wool and placed in a draining rack for the smear to air dry. It was examined microscopically using $\times 100$ oil immersion objective (Gram negative retained the counter stain as pink or dark red, while gram positive retain the primary stain dark purple or violet colour) ${ }^{[3]}$.

\section{Biochemical Tests}

Pure isolates of microorganisms grown on CHROMagar $^{\mathrm{TM}}$ Orientation plates were further identified biochemically. The different biochemical tests used in this study were: indole, citrate, catalase and coagulase tests. The protocols for these tests were adopted from ${ }^{[3]}$. 
Table 1 Biochemical tests used in the identification of the bacterial isolates

\begin{tabular}{lccccc}
\hline $\begin{array}{l}\text { Biochemical and } \\
\text { Enzymes Test }\end{array}$ & $\begin{array}{c}\text { Escherichia } \\
\text { Coli }\end{array}$ & $\begin{array}{c}\text { Enterococcus } \\
\text { Faecalis }\end{array}$ & $\begin{array}{c}\text { Klebsiella } \\
\text { Pneumoniae }\end{array}$ & $\begin{array}{c}\text { Staphylococcus } \\
\text { sciuri }\end{array}$ & $\begin{array}{c}\text { Proteus } \\
\text { Mirabilis }\end{array}$ \\
\hline Indole Test & + & - & + & - & + \\
Catalase Test & - & + & + & + & + \\
Coagulase Test & - & - & - & - & - \\
Citrate Test & - & - & + & - & + \\
\hline
\end{tabular}

Key: (-) Negative, (+) Positive

\section{Molecular Identification of Isolates from CHROMagar $^{\mathrm{TM}}$ Orientation \\ Polymerase Chain Reaction Test}

This involves several cycles of denaturation of sample DNA, annealing of specific primers to the target sequence (if present), and the extension of this sequence as facilitated by a thermostable polymerase leading to replication of a duplicate DNA sequence, in an exponential manner, to a point which will be visibly detectable by gel electrophoresis with the aid of a DNAintercalating chemical which fluoresces under UV $\operatorname{light}^{[24]}$.

\section{Agarose Gel Electrophoresis}

DNA can be quantified by cutting the DNA with a restriction enzyme, running it on an agarose gel, staining with ethidium bromide or a different stain and comparing the intensity of the DNA with a DNA marker of known concentration. DNA is negatively charged protein migrates towards negatively charge poles or corner on Agarose Gel Electrophoretic tank. Agarose Gel Electrophoretic tank contain sample wells of about $10 \mu \mathrm{l}$ each and a ladder well of about $8 \mu 1$, programmed for 25 minutes at 130 volts $^{[24]}$.

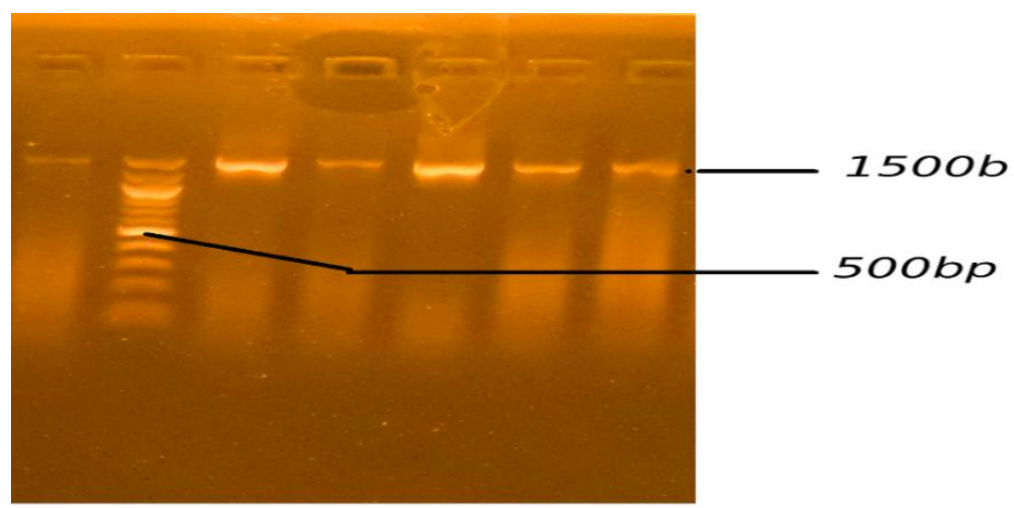

Figure 1 Agarose Gel Electrophoresis of 16SrRNA Gene Band of the Bacterial Isolates

Agarose gel electrophoresis in figure 4.1 result shows the ladder (control) and the presence of 16s rRNA gene bands of the six bacterial isolates. The presence of $16 \mathrm{~s}$ rRNA gene are shown at $1500 \mathrm{bp}$ (Figure 4.1).

\section{Banana Extracts and Control Drugs (Synthetic Antibiotic) Sensitivity Testing}

Determination of antimicrobial testing was done using a loop full growth of already detected isolates (about $0.2 \mathrm{ml}$ ) and was seeded into $2 \mathrm{ml}$ of already prepared peptone water for inoculations. A sterile cotton swab was then dipped into the overnight inoculum, thereafter; the surface of the plate was swabbed thoroughly with a sterile spreader and were rotated approximately to ensure an even distribution. The plates were allowed to dry at room temperature for about 5-10 minutes. Several punched holes of $6 \mathrm{~mm}$ were made on the sterile nutrient agar plates with the aid of a cork borer (flame sterilized) for well diffusion technique ${ }^{[3]}$. Also, $50 \mu$ l of both water and ethanol extracts of different concentrations (100\%, 80\%, $60 \%, 40 \%$ \& 20\%) were aseptically dispensed into each respective well. The plates were incubated alongside with the plates containing the 
synthetic drugs as control (Oxoid) at $37^{0} \mathrm{C}$ for 24 hours (DHP-9053A Heating Incubator).

Thereafter, sensitivity of both the banana peels extracts and the synthetic drugs as control were determined by measurement of diameter of zones of inhibition measured in millimetres $(\mathrm{mm})^{[1]}$.

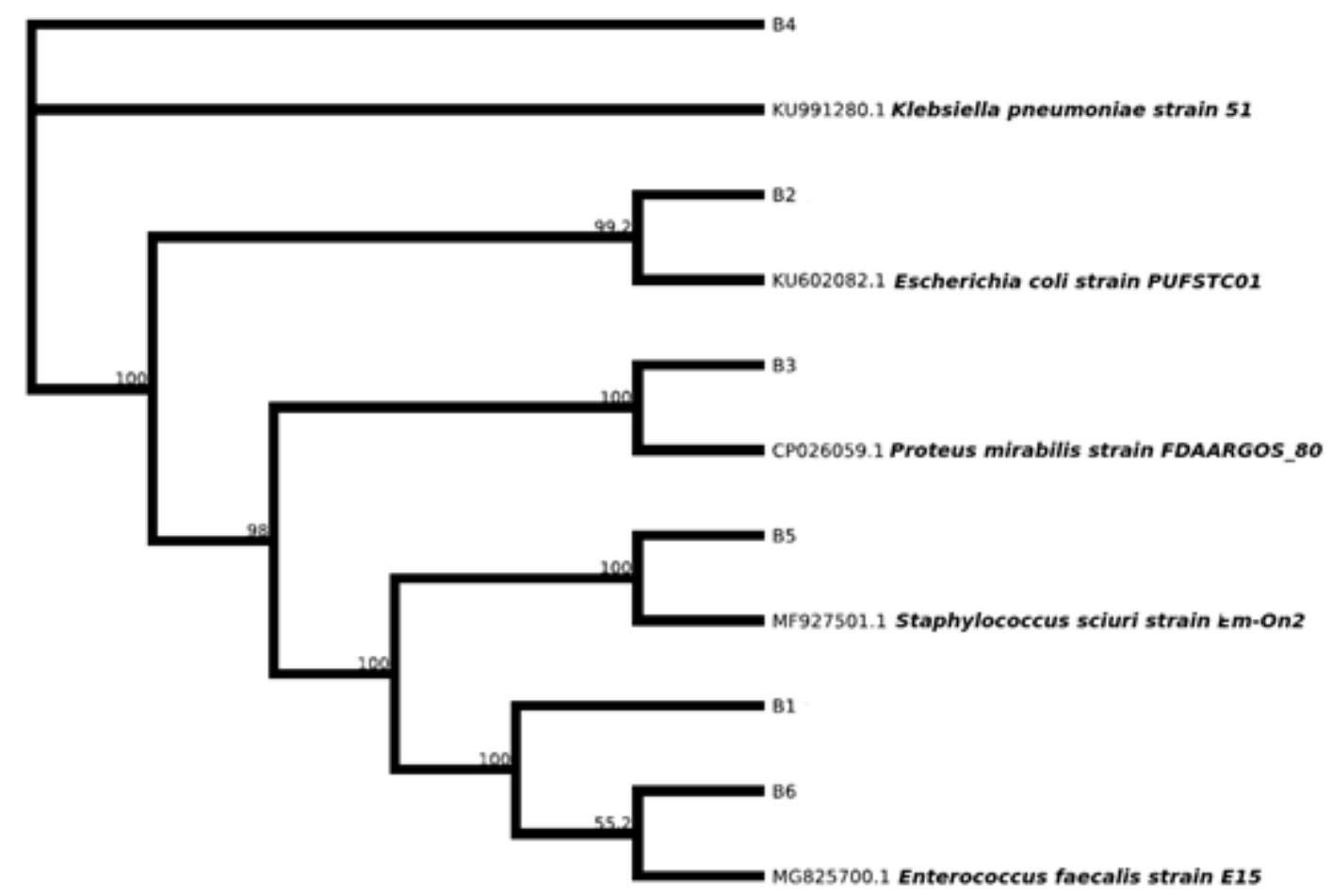

Figure 2 Phylogenetic Analysis

The Agarose Gel Electrophoresis result shows the presence of the 16s rRNA gene bands at $1500 \mathrm{bp}$ and the control ladder of the UTIs bacterial isolates in figure 4.1. The isolate was further sent for sequencing, and the obtained 16S rDNA sequence from the isolate produced an exact match during the megablast search for highly similar sequences from the NCBI non-redundant nucleotide $(\mathrm{nr} / \mathrm{nt})$ database $^{[19]}$. The $16 \mathrm{~S}$ rDNA of the isolate showed a percentage similarity to other species at $99 \%$. The evolutionary distances computed using the Jukes-Cantor method were in agreement with the phylogenetic placement of the $16 \mathrm{~s}$ rDNA of the isolates ${ }^{[6]}$, within the Enterococcus species (B1) and revealed a closely relatedness to Enterococcus faecalis strain E15 than other Enterococcus species (Fig. 4.2). The Escherichia coli species (B2) and revealed a closely relatedness to Escherichia coli strain PUFSTC01 than other E. coli (Fig. 4.2). The Proteus mirabilis (B3) and revealed a closely relatedness to Proteus mirabilis strain FDAARGOS_80 than another Proteus mirabilis (Fig. 4.2). The Klebsiella species (B4) and revealed a closely relatedness to Klebsiella pnuemoniae strain 51 than other Klebsiella species (Fig. 4.2). The Staphylococcus aureus (B5) and revealed a closely relatedness to Staphylococcus sciuri strain Em-on2 than other Staphylococcus aureus.

\section{Statistical Analysis}

The obtained data were entered and analysed using Statistical Package for Social Science (SPSS) version 20. The descriptive data was presented as means \pm standard deviation (SD).

\section{Results and Discussions}

This study was concerned with evaluating the medicinal and pharmacological effects of extracts of Musa sapientum L. peels on organisms obtained from subjects who had urinary tract infection. Both fresh ripe and dried ripe forms of 
the peels were used. The peels were obtained from the same bunch of banana sample (Musa sapientum L.). However, urinary tract infection appears to be the most common illness in all ages affecting both male and female, although the female tends to show a higher occurrence due to their anatomy, which also include the close proximity between the anus and the vagina ${ }^{[16]}$.

Table 2 Qualitative Screening for Active Phytochemical Components of Water, Ethanol and Control of Banana Peels Extract

\begin{tabular}{|c|c|c|c|c|c|}
\hline \multirow{2}{*}{$\begin{array}{l}\text { Types of Solvents, } \\
\text { Control/Active Components. } \\
\text { Banana Extracts }\end{array}$} & \multicolumn{2}{|c|}{ Ethanol Extract } & \multicolumn{2}{|c|}{ Water Extract } & \multirow{2}{*}{$\begin{array}{c}\text { Negative } \\
\text { Control } \\
\text { Ethanol }(\mathbf{7 0 \%}) \\
\end{array}$} \\
\hline & Fresh Ripe & Dry Ripe & Fresh Ripe & Dry Ripe & \\
\hline Saponins & - & + & - & - & - \\
\hline Alkaloids & ++ & ++ & + & + & - \\
\hline Tannins & + & + & - & - & - \\
\hline Flavonoid & + & ++ & - & - & - \\
\hline Cardiac glycosids & - & ++ & + & + & - \\
\hline Phenols & - & ++ & - & - & - \\
\hline
\end{tabular}

Key = (++) Absolutely Detected, (+) Moderately Detected, (-) Not Detected

The results obtained from the phytochemical test (Table 4.1) carried out shows that banana peels of Musa sapientum L. contain some bioactive compounds. Their potency was also enhanced by the type of solvent used, which show that some bioactive ingredients in the banana peel could dissolve well in ethanol solvent than water. The various bioactive ingredients were found in banana peels of fresh ripe and dry ripe of Musa sapientum L. peel using ethanol and water solvents as shown in table 4.1. It was observed that different bioactive constituents of the banana peels were soluble based on the polarity of the individual solvents. For example, in ethanol extract, the phytochemical contents are alkaloids, tannins and flavonoid for fresh ripe. The dry ripe shows the presence of saponin, alkaloids, tannins, flavonoids, cardiac glycosids and phenols. Water extract shows the presents of only alkaloids and cardiac glycosids for both fresh ripe and dry ripe. The dry ripe banana peels extract with ethanol solvent has more of the bioactive compounds followed by the fresh ripe. Presence of secondary metabolites could also be responsible for the antimicrobial activity or function of the banana peels. Some medicinal plant and aromatic compounds had been found to be a good source of bioactive component that are responsible for inhibiting some bacterial pathogens by precipitate the bacterial proteins, which could affect the bacterial peptidoglycan ${ }^{[1]}$. The water solvent were polar in nature and could not mix proper ${ }^{[18]}$. The fresh ripe and dry ripe banana peels show a greater level of active components in ethanol solvent, seconded by fresh ripe and dry ripe in water solvent. This indicate a little presence of active component in water solvent, which agrees with Singh \& Singh, (2000), for the use of organic solvents to be more suitable for phytochemical extractions. 
Tab.3 Zone of Inhibitions (MM) for $100 \%$ Concentration of Water-Soluble Extract on UTIs Isolates and

CLSI Standard

\begin{tabular}{|c|c|c|c|c|c|c|c|c|}
\hline $\begin{array}{l}\text { UTIs isolates/Banana Peel } \\
\text { Extracts and Sensitivity } \\
\text { Reference Range }\end{array}$ & 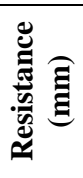 & 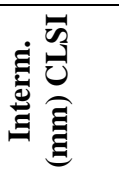 & 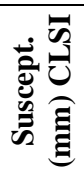 & 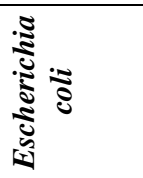 & 胥 & $\frac{2}{2}$ & 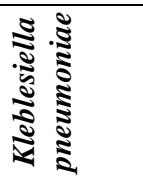 & 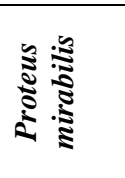 \\
\hline $\begin{array}{l}\text { FR } \\
(\mathrm{mg} / \mathrm{ml})\end{array}$ & $\leq 12$ & 13 & $\geq 15$ & $\begin{array}{l}12 \pm 1.1 \\
\text { Inter. }\end{array}$ & $\begin{array}{l}13 \pm 0.5 \\
\text { Inter. }\end{array}$ & $\begin{array}{l}10 \pm 1.5 \\
\text { Resist. }\end{array}$ & $\begin{array}{l}12 \pm 1.5 \\
\text { Inter. }\end{array}$ & $\begin{array}{l}13 \pm 0.5 \\
\text { Inter. }\end{array}$ \\
\hline $\begin{array}{l}\mathrm{DR} \\
(\mathrm{mg} / \mathrm{ml})\end{array}$ & $\leq 12$ & 13 & $\geq 15$ & $\begin{array}{l}14 \pm 1.5 \\
\text { Inter. }\end{array}$ & $\begin{array}{c}15 \pm 1.0 \\
\text { Inter. }\end{array}$ & $\begin{array}{l}10 \pm 1.5 \\
\text { Resist. }\end{array}$ & $\begin{array}{l}13 \pm 0.5 \\
\text { Inter. }\end{array}$ & $\begin{array}{c}15 \pm 1.5 \\
\text { Inter. }\end{array}$ \\
\hline Ciprofloxacin $(10 \mu \mathrm{g})$ & $\leq 15$ & $16-20$ & $\geq 21$ & $\begin{array}{l}15 \pm 1.0 \\
\text { Inter. }\end{array}$ & $\begin{array}{l}15 \pm 1.1 \\
\text { Inter. }\end{array}$ & $\begin{array}{l}15 \pm 1.5 \\
\text { Inter. }\end{array}$ & $\begin{array}{c}22 \pm 1.5 \\
\text { Suscept. }\end{array}$ & $\begin{array}{c}16 \pm 1.0 \\
\text { Inter. }\end{array}$ \\
\hline Streptomycin $(30 \mu \mathrm{g})$ & $\leq 12$ & $13-15$ & $\geq 16$ & $\begin{array}{l}00 \\
\text { Resist. }\end{array}$ & $\begin{array}{l}14 \pm 1.0 \\
\text { Inter. }\end{array}$ & $\begin{array}{r}18 \pm 4.9 \\
\text { Suscept. }\end{array}$ & $\begin{array}{c}00 \\
\text { Resist. }\end{array}$ & $\begin{array}{l}12 \pm 1.5 \\
\text { Inter. }\end{array}$ \\
\hline Chloramphenicol $(30 \mu \mathrm{g})$ & $\leq 13$ & $14-22$ & $\geq 23$ & $\begin{array}{l}21 \pm 1.0 \\
\text { Inter. }\end{array}$ & $\begin{array}{l}13 \pm 1.1 \\
\text { Inter. }\end{array}$ & $\begin{array}{l}13 \pm 1.0 \\
\text { Inter. }\end{array}$ & $\begin{array}{l}12 \pm 1.2 \\
\text { Resist. }\end{array}$ & $\begin{array}{c}00 \\
\text { Resist. }\end{array}$ \\
\hline Gentamycin $(10 \mu \mathrm{g})$ & $\leq 12$ & $13-14$ & $\geq 15$ & $16 \pm 0.5$ & $11 \pm 1.0$ & $\begin{array}{c}00 \\
\text { Resist }\end{array}$ & 00 & $12 \pm 1.0$ \\
\hline Erythromycin $(10 \mu \mathrm{g})$ & $\leq 13$ & $14-22$ & $\geq 23$ & $\begin{array}{c}\text { Suscept. } \\
00 \\
\text { Resist. }\end{array}$ & $\begin{array}{c}\text { Resist. } \\
00 \\
\text { Resist. }\end{array}$ & $\begin{array}{c}\text { Resist. } \\
17 \pm 1.0 \\
\text { Inter. }\end{array}$ & $\begin{array}{l}\text { Resist. } \\
00 \\
\text { Resist. }\end{array}$ & $\begin{array}{c}\text { Inter. } \\
00 \\
\text { Resist. }\end{array}$ \\
\hline
\end{tabular}

Tab.4. Zone of Inhibitions (MM) For 80\% Concentration of Water-Soluble Extract on UTIs Isolates and CLSI Standard

\begin{tabular}{|c|c|c|c|c|c|c|c|c|}
\hline $\begin{array}{l}\text { UTIs isolates/Banana } \\
\text { Peel Extracts and } \\
\text { Sensitivity Reference } \\
\text { Range. }\end{array}$ & 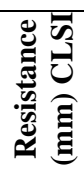 & 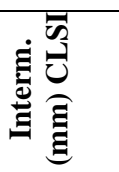 & 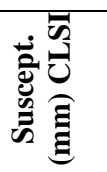 & 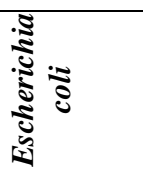 & 胥 & 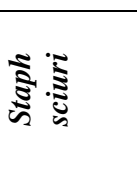 & 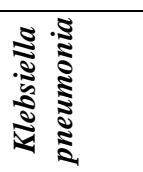 & 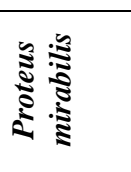 \\
\hline $\begin{array}{l}\text { FR } \\
(\mathrm{mg} / \mathrm{ml})\end{array}$ & $\leq 12$ & 13 & $\geq 15$ & $\begin{array}{l}8.3 \pm 1.5 \\
\text { Resist. }\end{array}$ & $\begin{array}{l}8.3 \pm 0.5 \\
\text { Resist. }\end{array}$ & $\begin{array}{c}00 \\
\text { Resist. }\end{array}$ & $\begin{array}{l}8.3 \pm 1.1 \\
\text { Resist. }\end{array}$ & $\begin{array}{l}9.0 \pm 1.0 \\
\text { Resist. }\end{array}$ \\
\hline $\begin{array}{l}\mathrm{DR} \\
(\mathrm{mg} / \mathrm{ml})\end{array}$ & $\leq 12$ & 13 & $\geq 15$ & $\begin{array}{l}9.6 \pm 1.1 \\
\text { Resist. }\end{array}$ & $\begin{array}{l}9.0 \pm 1.0 \\
\text { Resist. }\end{array}$ & $\begin{array}{l}7.5 \pm 0.7 \\
\text { Resist. }\end{array}$ & $\begin{array}{l}10 \pm 1.0 \\
\text { Resist. }\end{array}$ & $\begin{array}{l}9.6 \pm 0.5 \\
\text { Resist. }\end{array}$ \\
\hline Ciprofloxacin $(10 \mu \mathrm{g})$ & $\leq 15$ & $16-20$ & $\geq 21$ & $\begin{array}{c}15 \pm 1.0 \\
\text { Inter. }\end{array}$ & $\begin{array}{l}15 \pm 1.1 \\
\text { Inter. }\end{array}$ & $\begin{array}{c}15 \pm 1.5 \\
\text { Inter. }\end{array}$ & $\begin{array}{l}22 \pm 1.0 \\
\text { Suscept. }\end{array}$ & $\begin{array}{l}16 \pm 1.0 \\
\text { Inter. }\end{array}$ \\
\hline Streptomycin $(30 \mu \mathrm{g})$ & $\leq 12$ & $13-15$ & $\geq 16$ & $\begin{array}{c}00 \\
\text { Resist. }\end{array}$ & $\begin{array}{l}14 \pm 1.0 \\
\text { Inter. }\end{array}$ & $\begin{array}{l}18 \pm 1.0 \\
\text { Suscept. }\end{array}$ & $\begin{array}{c}00 \\
\text { Resist. }\end{array}$ & $\begin{array}{c}12 \pm 1.5 \\
\text { Inter }\end{array}$ \\
\hline $\begin{array}{l}\text { Chloramphenicol } \\
(30 \mu \mathrm{g})\end{array}$ & $\leq 13$ & $14-22$ & $\geq 23$ & $\begin{array}{l}21 \pm 1.0 \\
\text { Inter. }\end{array}$ & $\begin{array}{l}13 \pm 1.1 \\
\text { Inter. }\end{array}$ & $\begin{array}{l}13 \pm 1.0 \\
\text { Inter. }\end{array}$ & $\begin{array}{l}12 \pm 1.0 \\
\text { Resist. }\end{array}$ & $\begin{array}{c}00 \\
\text { Resist. }\end{array}$ \\
\hline Gentamycin $(10 \mu \mathrm{g})$ & $\leq 12$ & $13-14$ & $\geq 15$ & $16 \pm 0.5$ & $11 \pm 1.0$ & 00 & 00 & $12 \pm 1.0$ \\
\hline Erythromycin $(10 \mu \mathrm{g})$ & $\leq 13$ & $14-22$ & $\geq 23$ & $\begin{array}{l}\text { Suscept. } \\
00 \\
\text { Resist. }\end{array}$ & $\begin{array}{l}\text { Resist. } \\
00 \\
\text { Resist. }\end{array}$ & $\begin{array}{l}\text { Resist. } \\
17 \pm 10 \\
\text { Inter. }\end{array}$ & $\begin{array}{l}\text { Resist. } \\
00 \\
\text { Resist. }\end{array}$ & $\begin{array}{l}\text { Inter. } \\
00 \\
\text { Resist. }\end{array}$ \\
\hline
\end{tabular}

Tab.5 Zone of Inhibitions (MM) for 100\% Concentration of Ethanol-Soluble Extract on UTIs Isolates and CLSI Standard

\begin{tabular}{|c|c|c|c|c|c|c|c|c|}
\hline $\begin{array}{lr}\text { UTIs isolates/Banana } \\
\text { Peel Extracts and } \\
\text { Sensitivity Reference } \\
\text { Range }\end{array}$ & 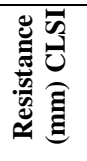 & 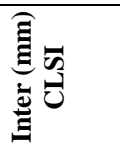 & 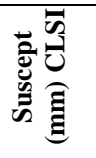 & 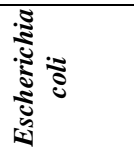 & 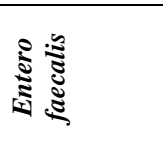 & 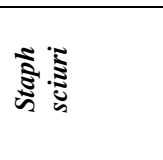 & 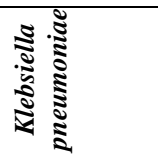 & 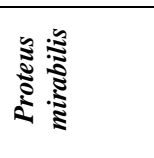 \\
\hline FR (mg/ml) & $\leq 12$ & 13 & $\geq 15$ & $\begin{array}{l}16 \pm 1.0 \\
\text { Inter. }\end{array}$ & $15 \pm 1.5$ Inter. & $12 \pm 2.0$ Inter. & $12 \pm 1.5$ Inter. & $\begin{array}{c}17 \pm 1.0 \\
\text { Suscept. }\end{array}$ \\
\hline DR (mg/ml) & $\leq 12$ & 13 & $\geq 15$ & $\begin{array}{c}21 \pm 5.8 \\
\text { Suscept. }\end{array}$ & $\begin{array}{c}21 \pm 1.5 \\
\text { Suscept. }\end{array}$ & $\begin{array}{l}11 \pm 1.0 \\
\text { Resist. }\end{array}$ & $14 \pm 1.5$ Inter. & $\begin{array}{c}17 \pm 1.5 \\
\text { Suscept. }\end{array}$ \\
\hline Ciprofloxacin $(10 \mu \mathrm{g})$ & $\leq 15$ & $16-20$ & $\geq 21$ & $\begin{array}{l}14 \pm 2.0 \\
\text { Resist. }\end{array}$ & $15 \pm 0.5$ Inter. & $17 \pm 0.5$ Inter. & $\begin{array}{c}22 \pm 1.0 \\
\text { Suscept. }\end{array}$ & $16 \pm 1.0$ Inter. \\
\hline Streptomycin $(30 \mu \mathrm{g})$ & $\leq 12$ & $13-15$ & $\geq 16$ & $\begin{array}{c}00 \\
\text { Resist. }\end{array}$ & $13 \pm 1.0$ Inter. & $\begin{array}{c}21 \pm 1.0 \\
\text { Suscept. }\end{array}$ & $\begin{array}{c}00 \\
\text { Resist. }\end{array}$ & $12 \pm 1.5$ Inter. \\
\hline Chloramphenicol $(30 \mu \mathrm{g})$ & $\leq 13$ & $14-22$ & $\geq 23$ & $\begin{array}{c}21 \pm 0.5 \\
\text { Suscept. }\end{array}$ & $13 \pm 1.0$ Inter. & $13 \pm 1.0$ Inter. & $\begin{array}{l}12 \pm 1.0 \\
\text { Resist. }\end{array}$ & $\begin{array}{c}00 \\
\text { Resist. }\end{array}$ \\
\hline Gentamycin $(10 \mu \mathrm{g})$ & $\leq 12$ & $13-14$ & $\geq 15$ & $\begin{array}{c}17 \pm 0.5 \\
\text { Suscept. }\end{array}$ & $13 \pm 1.0$ Inter. & $\begin{array}{c}00 \\
\text { Resist. }\end{array}$ & $\begin{array}{c}00 \\
\text { Resist }\end{array}$ & $12 \pm 1.0$ Inter. \\
\hline Erythromycin $(10 \mu \mathrm{g})$ & $\leq 13$ & $14-22$ & $\geq 23$ & $\begin{array}{c}00 \\
\text { Resist. }\end{array}$ & $\begin{array}{c}00 \\
\text { Resist. }\end{array}$ & $\begin{array}{c}17 \pm 1.0 \\
\text { Inter. }\end{array}$ & $\begin{array}{c}00 \\
\text { Resist. }\end{array}$ & $\begin{array}{c}00 \\
\text { Resist. }\end{array}$ \\
\hline
\end{tabular}

Mean \pm S.E.M $=$ Mean values \pm Standard error of means 
Tab.6 Zone of Inhibitions (MM) for 80\% Concentration of Ethanol-Soluble Extract on UTIs Isolates and CLSI Standard

\begin{tabular}{|c|c|c|c|c|c|c|c|c|}
\hline $\begin{array}{ll}\text { UTIs } & \\
\text { isolates/Banana } & \text { Peel } \\
\text { Extracts } \quad \text { and } \\
\text { Sensitivity Reference } \\
\text { Range }\end{array}$ & 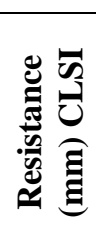 & 离泀 & 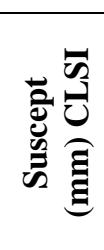 & 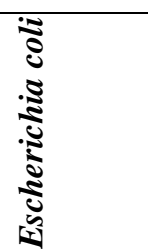 & 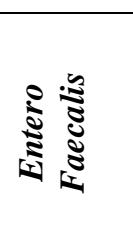 & 离 & 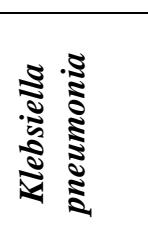 & 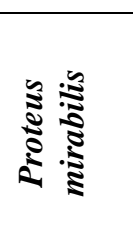 \\
\hline $\begin{array}{l}\text { FR } \\
(\mathrm{mg} / \mathrm{ml})\end{array}$ & $\leq 12$ & 13 & $\geq 15$ & $\begin{array}{l}12 \pm 1.1 \\
\text { Inter. }\end{array}$ & $\begin{array}{c}13 \pm 2.0 \\
\text { Inter. }\end{array}$ & $\begin{array}{l}8.3 \pm 1.5 \\
\text { Resist. }\end{array}$ & $\begin{array}{l}10 \pm 1.0 \\
\text { Resist. }\end{array}$ & $\begin{array}{c}13 \pm 1.0 \\
\text { Inter. }\end{array}$ \\
\hline DR & $\leq 12$ & 13 & $\geq 15$ & $\begin{array}{l}14 \pm 2.0 \\
\text { Inter. }\end{array}$ & $\begin{array}{l}14 \pm 1.5 \\
\text { Inter. }\end{array}$ & $\begin{array}{c}00 \\
\text { Resist. }\end{array}$ & $\begin{array}{l}11 \pm 1.7 \\
\text { Resist. }\end{array}$ & $\begin{array}{l}12 \pm 1.5 \\
\text { Inter. }\end{array}$ \\
\hline Ciprofloxacin $(10 \mu \mathrm{g})$ & $\leq 15$ & $16-20$ & $\geq 21$ & $\begin{array}{l}14 \pm 2.0 \\
\text { Resist. }\end{array}$ & $\begin{array}{l}15 \pm 0.5 \\
\text { Inter. }\end{array}$ & $\begin{array}{l}17 \pm 0.5 \\
\text { Inter. }\end{array}$ & $\begin{array}{l}22 \pm 1.0 \\
\text { Suscept. }\end{array}$ & $\begin{array}{l}16 \pm 1.0 \\
\text { Inter. }\end{array}$ \\
\hline Streptomycin $(30 \mu g)$ & $\leq 12$ & $13-15$ & $\geq 16$ & $\begin{array}{c}00 \\
\text { Resist. }\end{array}$ & $\begin{array}{l}13 \pm 1.0 \\
\text { Inter. }\end{array}$ & $\begin{array}{l}21 \pm 1.0 \\
\text { Suscept. }\end{array}$ & $\begin{array}{c}00 \\
\text { Resist. }\end{array}$ & $\begin{array}{l}12 \pm 1.5 \\
\text { Inter. }\end{array}$ \\
\hline $\begin{array}{l}\text { Chloramphenicol } \\
(30 \mu g)\end{array}$ & $\leq 13$ & $14-22$ & $\geq 23$ & $\begin{array}{r}21 \pm 0.5 \\
\text { Suscept. }\end{array}$ & $\begin{array}{l}13 \pm 1.0 \\
\text { Inter. }\end{array}$ & $\begin{array}{l}13 \pm 1.0 \\
\text { Inter. }\end{array}$ & $\begin{array}{l}12 \pm 1.0 \\
\text { Resist. }\end{array}$ & $\begin{array}{c}00 \\
\text { Resist. }\end{array}$ \\
\hline Gentamycin $(10 \mu \mathrm{g})$ & $\leq 12$ & $13-14$ & $\geq 15$ & $\begin{array}{l}17 \pm 0.5 \\
\text { Suscept. }\end{array}$ & $\begin{array}{l}13 \pm 1.0 \\
\text { Inter. }\end{array}$ & $\begin{array}{c}00 \\
\text { Resist. }\end{array}$ & $\begin{array}{c}00 \\
\text { Resist. }\end{array}$ & $\begin{array}{l}12 \pm 1.0 \\
\text { Inter. }\end{array}$ \\
\hline Erythromycin $(10 \mu \mathrm{g})$ & $\leq 13$ & $14-22$ & $\geq 23$ & $\begin{array}{c}00 \\
\text { Resist. }\end{array}$ & $\begin{array}{c}00 \\
\text { Resist. }\end{array}$ & $\begin{array}{l}17 \pm 1.0 \\
\text { Inter. }\end{array}$ & $\begin{array}{c}00 \\
\text { Resist. }\end{array}$ & $\begin{array}{c}00 \\
\text { Resist. }\end{array}$ \\
\hline
\end{tabular}

KEY: (CLSI) - Clinical and Laboratory Standard Institute, (FR)- Fresh Ripe banana peels, (DR)- Dry Ripe banana peels, (Suscept)-Susceptibility, (Inter) - Intermediate zone, (Resist)- Resistance and 00 -Absent

The results obtained from this (table 4.4) study indicate that the $100 \%$ water-soluble extracts produced smaller zones of inhibition than the standard drugs for Escherichia coli. Fresh ripe shows an intermediate size of zone of inhibition, were as the dry ripe were susceptible to the isolate, according to clinical laboratory standard institute, (2017). This means that their pharmacological effects are less potent than the standard drugs. Although, the standard drugs that were effective on Escherichia coli were chloramphenicol, ciproflaxin and gentamycin. Also, both the fresh and dried ripe banana peels used produced almost the same zones of inhibition for Enterococcus faecalis with the standard drugs. The standard drugs that were effective on this isolate were ciproflaxin, streptomycin and chloramphenicol. It was also observed that in table (4.4) both the fresh and dried ripe banana peels used produced less zones of inhibition for Staphylococcus sciuri than the standard drugs. The zone of inhibition for fresh ripe and dry ripe indicates that the peels were resistance to the isolate. The standard drugs that were effective are ciproflaxin, streptomycin, chloramphenicol and erythromycin, while gentamycin were also resistance to the isolate. The extract of both the fresh and dried ripe banana peels used, produced less zones of inhibition for Klebsiella pneumoniae than the standard drugs. The fresh ripe and dry ripe shows only an intermediate size of zone of inhibition to the isolate ${ }^{[4]}$. Although, the standard drug that were effective on Klebsiella pneumoniae was ciproflaxin and chloramphenicol were resistance. The banana peels extract used produced less zones of inhibition for Proteus mirabilis than the standard drugs. Both the fresh ripe and dry ripe shows an intermediate size of zone of inhibitions to the isolate. This could be possible properly because the peels were dehydrated which contributes to the accumulation or more dry ripe peels by weight before soaking. Although, the standard drugs that were effective on Proteus mirabilis were ciproflaxin, streptomycin and gentamycin. According to Ayuba et al., (2016), the "degree of susceptibility of the extract was concentration dependent, that is the higher the concentration of an extract the larger or wider the size of zone of inhibition likewise the lower concentrations". 
Besides, a similar observation was noticed when the extract (table 4.5) were diluted to $80 \%$ watersoluble extract. The results obtained from this study indicate that the $80 \%$ concentration of water-soluble extract produced smaller zones of inhibition for Escherichia coli, Enterococcus faecalis, Staphylococcus sciuri, Klebsiella pneumoniae and Proteus mirabilis than the standard drugs. The fresh ripe and dry ripe were all resistance to the isolates. Although, the standard drugs that were effective on Escherichia coli were ciprofloxacin, chloramphenicol and gentamycin. The standard drugs that were effective on Enterococcus faecalis were ciprofloxacin, streptomycin, chloramphenicol and gentamycin. For Proteus mirabilis were ciproflaxin, streptomycin and gentamycin. For Klebsiella pneumoniae the standard drugs that were effective are ciproflaxin and chloramphenicol. Staphylococcus sciuri were ciproflaxin, chloramphenicol and erythromycin. The impressive colonizing capacity of this species may result from its broad range of biochemical activities, which includes the ability to use inorganic nitrogen salts as the sole source of nitrogen ${ }^{[25]}$. However, they are also important human pathogens responsible for urinary tract infection and others ${ }^{[11],[23]}$. This research contradict Zainab et al., (2013) that says the aqueous banana extracts have some inhibitory effect to gram-positive bacteria. Water solvent could not also dissolved some bioactive compounds for antimicrobial activities due to its low selective properties in nature ${ }^{[17]}$.

The findings for the $100 \%$ ethanol-soluble extract of fresh ripe and dried ripe banana peels used produced similar zones of inhibition for Escherichia coli with the standard drugs in table (4.6). All the peels extract were susceptible to the isolate led by the dry ripe banana peels on Escherichia coli and Enterococcus faecalis. Also, the standard drugs that were effective on the isolates were same as previously discussed.

Similar observation was seen in the $80 \%$ ethanolsoluble extract in table (4.7) of the fresh ripe and dried ripe banana peels used, which produced less zones of inhibition for Escherichia coli, $E$. faecalis, $P$. mirabilis than the standard drugs. The extracts had less potency as indicated by the zones of inhibition compared to the standard drugs on Staphylococcus sciuri and K. pneumonia ${ }^{[4]}$. Although, the standard drugs that were effective on where same as discussed above. The results from some studies showed that $S$. sciuri has a wide spectrum of possible virulence factors. Moreover, some of the factors displayed activities similar to those of pathogenic staphylococci ${ }^{[22]}$.

Ethanol is miscible with water and many organic solvents and is a good general purpose solvent unlike the polar solvent (water) that is not miscible with oil ${ }^{[13]}$. The low boiling point of ethanol means that the solvent evaporates quickly and does not remain on the solute. Ethanol were used in the production of some antibiotics for example, the solvent function to keeps the impurities in the solution so the active ingredient is selectively removed from the reaction mixture by extraction. That is while often, high concentrations is used to dissolve many waterinsoluble medications, herbs and related compounds ${ }^{[13]}$. Based on its unique function of denaturing the proteins, dissolving lipids of microorganisms against most bacteria, fungi and many viruses. According to Mcdonnell \& Russell, (1999), 70\% ethanol is the most effective concentration, particularly because of osmotic pressure, that enhance the action of the extract.

\section{Conclusion}

This study has shown that the aqueous extract of both fresh ripe and dry ripe banana peel of Musa sapientum could be considered as a good antimicrobial agent for urinary tract isolates alongside with the synthetic medicines. The present of some secondary metabolites, in both water and ethanol extract of banana peels indicates some significant inhibitory activities on urinary tract isolates. Although, the ethanol extract shows more of these phytochemicals than the water extracts. Meanwhile, ethanol extracts of 
Musa sapientum peels exhibits some antimicrobial potential or activities on the tests organisms. Finally, there was a synergetic effect from Musa sapientum peels and $70 \%$ ethanol on the urinary tract isolates.

\section{Recommendation}

A good study should be encouraged on any possible toxic effect from consuming these peels on human using laboratory rats and appropriate dose recommend for therapeutic consumption.

Consent: It is not applicable.

Competing Interests: Authors have declared that no competing interests exist.

\section{Ethical Approval}

Ethical approval was sought and obtained from the ethical committee of Rivers State Hospital Management Board, Port Harcourt. Hence, permission to work on the urine samples with form queried for UTIs coming into Medical microbiology unit of the laboratory section in BMSH. Also, a copy of the written Ethical Approval letter is available for review by the Editorial office/Chief Editor/Editorial Board members of this journal.

\section{Authors' contributions}

The entire work was done by author KFE, NEG Author WCK gave an idea for this work. All authors read and approved the final manuscript

\section{References}

1. Ayuba SB, Ikya HP, Ifeanyi TO, Oluboyo BO, Akele YR, Akinseye JF, et al. Antibacterial Activities of Selected Fruit Peels against Organisms Associated with Urinary Tract Infection. Intern $\mathbf{J}$ Current Microb and Applied Sc.2016:5(12):265-72.

2. Bhat R, Rai RV, Karim AA. Mycotoxins in Food and Feed: Present Status and Future Concerns.
Comp Rev in Food Sc and Food Safety.2010:9:57-81.

3. Cheesbrough M. District Laboratory Practice in Tropical Countries, Part 11. 2nd ed. Cambridge, UK Cambridge University Press; 2000.

4. Clinical and Laboratory Standards Institute (CLSI). Performance Standards for Antimicrobial Susceptibility Testing. 27th ed. Informational Supplement. CLSI Document M100-S26. Wayne, PA; 2017.

5. Ehiowemwenguan G, Emoghene AO, Inetianbor JE. Antibacterial and Phytochemical Analysis of Banana Fruit Peel. Intern Org of Sc Research. 2014:4(8):18-25.

6. Felsenstein J. Confidence Limits on Phylogenies. An Approach Using the Bootstrap. Evolution. 1985:39:783-91.

7. Flores-Mireles AL, Walker JN, Caparon M, Hultgren SJ. Urinary Tract Infections. Epidemiology, Mechanisms of Infection and Treatment Options. Nature Reviews. Microb. 2015:13(5):269-84.

8. Geerlings SE. Prevention of Recurrent Urinary Tract Infections in Women. Antimicrobial and Nonantimicrobial Strategies. Infect Dis Clin North America.2014:28:135- 38.

9. Happi ET, Bindelle J, Agneesens R, Buldgen A, Wathelet B, Paquot $M$. Ripening Influences Banana and Plantain Peels Composition and Energy Content. Trop Animal Health Prod Journal. 2011:43(1):171 - 77.

10. Imam MZ, Akter S. Musa paradisiaca and Musa sapientum. Phytochemical and Pharmacological Review. J Applied Pharm Sc. 2011:1:14 - 20.

11. Kolawole DO, Shittu AO. (1997). Unusual Recovery of Animal Staphylococci from Septic Wounds of Hospital Patients in Ile-Ife, Nigeria. Lett Applied Microb. 1997:24:87-90. 
12. Konne FE, Monsi TP, Wokem GN. Bacteriology of Suya Meat Sold in Bonny Local Government Area, Rivers State. Asian J Med and Health. 2018:10(4): 1-7.

13. Mcdonnell G, Russell AD. "Antiseptics and Disinfectants: Activity, Action, and Resistance". Clin Microb Rev. 1999:12(1): 147-79.

14. Merlion J, Ginn A, Zong Z, Wiklendt A, Thomas L, Gottlieb T, et al. Evaluation of CHROMagar Orientation for Differentiation and Presumptive Identification of Gram Negative Bacilli and Enterococcus species. J Clin Microb. 1996:34:1788-793.

15. National Committee for Clinical Laboratory Standards. Methods for Dilution Antimicrobial Susceptibility Tests for Bacteria That Grow Aerobically. Approved Standard. 6th ed. Document M7-A6. Wayne, Pa; 2003.

16. Nicolle S, Lindsay E, Bradley R, Colgan S, Hooton M. Infectious Diseases Society of America Guidelines for the Diagnosis and Treatment of Asymptomatic Bacteriuria in Adults. Clin Infectious Dis. 2005:40(5):643-54.

17. Nostro A, Germano M, D'angelo V, Marino A, Cannatelli M. Extraction Methods and Bioautography for Evaluation of Medicinal Plant Antibacterial Activity. Lett Applied Microb. 2000:30(5):379-84.

18. Onesios KM, Yu EJ, Bouwer J. Biodegradation and Removal of Pharmaceuticals and Personal Care Products in Treatment Systems: A Review. Biodegradation. 2009:20:441-66.

19. Saitou N, Nei M. The Neighbor-joining Method. A New Method for Reconstructing Phylogenetic Trees. Mol Biol and Evol. 1987:4:406-25.
20. Shadam A, Sundaram S, Rai G K. (2014). Nutraceutical Application and Value Addition of Banana Peel. A Review. Intern J Pharm Sc. 2014:6:81 - 5.

21. Singh I, Singh VP. (2000). Antifungal Properties of Aqueous and Organic Solution Extracts of Seed Plants against Aspergillus flavus and A. niger. Phytomorphy. 2000:50:151-57.

22. Stepanovic S, Dakic I, Djukic S, Lozuk B, Svabic-Vlahovic M. Surgical Wound Infection Associated with Staphylococcus sciuri. Scand J Infect Dis. 2002:34:68586.

23. Stepanovic S, Jezek P, Vukovic D, Dakic I, Petras P. Isolation of Members of The Staphylococcus sciuri Group from Urine and Their Relationship to Urinary Tract Infections. J Clin Microb. 2003:41:526264.

24. Turnidge J, Peterson DL. Setting and Revising Antibacterial Susceptibility Breakpoints. Clin Microb Rev.2007:20(3):391-98.

25. Weinstein MP, Mirrett S, Van Pelt L, Mckinnon M, Zimmer BL, Kloos W. et al. Clinical Importance of Identifying Coagulase-Negative Staphylococci Isolated from Blood Cultures. Evaluation of Microscan Rapid and Dried Overnight Gram-Positive Panels versus a Conventional Reference Method. J of Clin Microb. 1998:36:2089-92.

26. Zainab AG, Chabuck 1, Alaa H, AlCharrakh 1, Nada KH, Shatha KH. Antimicrobial Effect of Aqueous Banana Peel Extract, Iraq. Pharm Sc. 2013:1:73-5. 